\title{
Cervical cancer cell proliferation inhibition by vanillin oxime through HIF-1a expression inhibition, ERK1/2 and Akt protein down-regulation
}

\author{
Hong-jing Chen ${ }^{1}$, Nai-ling $\mathrm{Li}^{2}$, Qiang Gu³ and Guang-Min Zhang ${ }^{4} \otimes$ \\ 1Department of Obstetrics and Gynecology, Nantong Maternal and Child Health Center, Nantong University, Jiangsu Nantong, 226006 China; \\ 2Department Maternity and Health Care, Maternal and Child Health Care and Planned Birth Service Center of Licheng County, Shanxi Province, \\ Shanxi Licheng 047600, China; ${ }^{3}$ Department of Mammary Division, Nantong Maternal and Child Health Center, Nantong University, Jiangsu \\ Nantong 226006, China; 'Department of Obstetrics and Gynecology, Chifeng Second Hospital, Neimenggu Chifeng 024000, China
}

Cervical cancer is a frequently reported cancer of reproductive tract in females and is worldwide 4th most common malignant tumor. The present study investigated the effect of vanillin oxime on proliferation of cervical cancer cells. Vanillin oxime treatment led to suppression of Caski cell proliferation but could not affect proliferation of $(\mathrm{HCvEpC})$ cells at the tested $(2$ to $10 \mu \mathrm{M})$ concentrations. In vanillin oxime treated Caski cells ROS level showed an increase with enhancement in concentration from 2 to $10 \mu \mathrm{M}$. Vanillin oxime treatment significantly $(P<0.0487)$ lowered the count of colonies and inhibited invasive abilities of Caski cells. Treatment with vanillin oxime caused a significant $(P<0.0487)$ suppression in HIF-1a expression in Caski cells. Caski cell apoptotic count reached to $8.76 \%$ and $48.65 \%$, on incubation with 2 and $10 \mu \mathrm{M}$ concentrations of vanillin oxime respectively. After treatment with vanillin oxime a prominent reduction in MMP-2 and -9 levels was observed in Caski cells. A prominent reduction in p-ERK $1 / 2$ and $p$-Akt levels was observed in Caski cells after treatment with vanillin oxime. Vanillin oxime inhibits cervical cancer proliferation, invasive abilities, induces apoptotic signalling, and elevates ROS production. Therefore, vanillin oxime may be developed as an effective therapeutic agent for treatment of cervical cancer.

Keywords: cervical cancer, apoptosis, vanillin oxime, ROS, HIF-1a expression

Received: 04 May, 20921; revised: 22 June, 2021; accepted: 09 September, 2021; available on-line: 02 March, 2022

$凶$ e-mail: guangminzhang.edu@yahoo.com

Abbreviations: $\mathrm{HCVEpC}$, human cervical epithelial cells; HIF-1a Hypoxia-inducible factor-1a

\section{INTRODUCTION}

Cervical cancer is a frequently reported cancer of reproductive tract in females and is worldwide 4th most common malignant tumor (Chen et al., 2020). Annually cervical cancer is detected in $\sim 500000$ patients globally and reports have shown increasing incidence among younger women over the past few years (Fitzmaurice et al., 2015; Wei et al., 2012). Surgery along with radiotherapy have shown significant improvement in the cervical cancer management in patients with early-stage of cancer (Sousa et al., 2018; McClung et al., 2019). However, the treatments available hardly effect tumor growth in patients having late-stage cancer and tumor recurrence. Patients with late-stage cervical cancer have very poor prognosis and it is reported that 1-year survival rate of such patients is below 20\% (Sousa et al., 2018; McClung et al., 2019). The comprehensive strategies, including surgery used for cervical cancer have failed to produce any breakthrough in the treatment of advanced and recurrent tumors (Su et al., 2019; Yang et al., 2014). Thus, identification of molecular targets and discovery of potent anti-tumor agents is required to improve the health and survival of patients and inhibit tumor development.

There are several reactive oxygen species (ROS) in human bodies which play important role in various metabolic regulatory processes like glucose metabolism (Jambunathan et al., 2010; Wang et al., 2018). ROS act as main signalling factors and regulate several processes including proliferation of cells, migration abilities, and cell differentiation by influencing various proteins and lipids (Lu et al., 2018; Diwanji et al., 2018; Sun et al., 2019). In addition, ROS also influence the functioning and structure of the blood vessels ( $\mathrm{Lu}$ et al., 2018; Diwanji et al., 2018; Sun et al., 2019). Higher content of ROS induces various disorders in the body by damaging various proteins and membranes.

Hypoxia-inducible factor- $1 \alpha$ (HIF-1 $\alpha$ ) has been found to play a prominent role in invasion of cancer cells, their metastatic ability, and proliferation (Zhang et al., 2017; Lai et al., 2018). Reports have demonstrated that HIF-1 $\alpha$ expression inhibition by therapeutic agents exhibits antitumor effect in many cancers such as breast and pulmonary cancer cells (Sun et al., 2011; Yang et al., 2014).

Vanillin, a phytoconstituent isolated from Vanilla planifolia plant is commonly known as 4-hydroxy-3-methoxybenzaldehyde. Initial screening revealed anti-microbial, inflammation inhibitory and anti-mutagenic activities of vanillin in rodent as well as human models (Walton et al., 2003; King et al., 2008; Srinivasan et al., 2008; Imanishi et al., 1990). Mechanistic study revealed that vanillin inhibits invasion and migration abilities of liver cancer cells by down-regulation of nuclear factor- $x \mathrm{~B}$ expression and suppression of matrix metalloproteinases (Liang et al., 2009). Moreover, vanillin treatment led to the inhibition of PI3K phosphorylation to suppress angiogenesis of lung cancer cells and formation of lamellipodia (Lirdprapamongkol et al., 2010; Lirdprapamongkol et al., 2005; Lirdprapamongkol et al., 2009). Vanillin treatment of cervical and breast cancer cells is associated with activation of apoptosis pathway and thereby inhibition of tumor growth (Lirdprapamongkol et al., 2010; Lirdprapamongkol et al., 2005; Lirdprapamongkol et al., 2009). Compound obtained by modification of many natural products has shown strong anticancer property exhibiting 
$81-82 \%$ cytotoxicity. Oxime analogs of curcumin have been found to possess strong antiproliferative property against cancer cells compared to the cyclohexanone and tetralone analogs (Qin et al., 2016). Taking into account string anticancer activity of oxime analogs of the natural products the present study investigated vanillin oxime as anti-proliferative agent against cervical cancer cells and elucidated the associated mechanism.

\section{EXPERIMENTAL}

\section{Reagents and chemicals}

Vanillin oxime (Cas number S539570; purity 99\%) and dimethyl sulfoxide were supplied by the Merck Chemicals. Dimethyl sulfoxide (DMSO) and many other chemicals were provided by the Sigma-Aldrich (St Louis, MO, USA). Stock solution of vanillin oxime was prepared in physiological saline.

\section{Cell lines and culture}

Caski cervical cancer cell line and human cervical epithelial cells (HCvEpC) cells were supplied by the Shanghai Bioengineering Co., Ltd., China. The cells were cultured overnight in RPMI-1640 medium mixed with FBS $(10 \%)$ in an incubator containing $\mathrm{CO}_{2}(5 \%)$ at $37^{\circ} \mathrm{C}$. At the time of entering logarithmic growth phase the cells were digested for $3 \mathrm{~min}$ on treatment with $0.25 \%$ pancreatin at $37^{\circ} \mathrm{C}$.

\section{Proliferation assay}

Caski and (HCvEpC) cells were inoculated in 96-well plates at a density of $2 \times 10^{4}$ cells / well and incubated for $24 \mathrm{~h}$ with vanillin oxime at $2,4,6,8$ and $10 \mu \mathrm{M}$ concentrations. Culture solution from the plates was removed at $24 \mathrm{~h}$ of incubation and then $10 \mu \mathrm{l}$ of MT'T $(5 \mathrm{mg} / \mathrm{ml})$ solution was added to each well. After $4 \mathrm{~h}$ of incubation with MT'T, $100 \mu \mathrm{l}$ DMSO was added to solubilize the formazan crystals that formed in each well. Measurement of absorbance was made three times for each plate at $450 \mathrm{~nm}$ using a microplate reader (Thermo, BD, USA, VLOLA0D2) for calculation of cell proliferation.

\section{Determination of ROS level}

Fluorescent dye namely, 2',7'-dichlorodihydrofluorescein diacetate ( $\mathrm{H}_{2} \mathrm{DCFDA}$; Invitrogen) was used for ROS content detection in Caski cells. The cells were incubated at $1 \times 10^{6}$ cells/ well distribution in 6-well plates for $24 \mathrm{~h}$ with 2 to $10 \mu \mathrm{M}$ concentrations of vanillin oxime at $37^{\circ} \mathrm{C}$. Afterwards cells were PBS washed twice before incubation for $40 \mathrm{~min}$ at $37^{\circ} \mathrm{C}$ with $20 \mu \mathrm{M}$ $\mathrm{H}_{2} \mathrm{DCFDA}$ as per the instructions of the supplier. Excitation and emission wavelengths used were 489 and 528 $\mathrm{nm}$, for detection of fluorescence using enzyme labeling instrument (Tecan Group, Ltd.) and for the determination of ROS content, respectively.

\section{Colony formation assay}

Caski cells growing in logarithmic phase were distributed at 1000 cells/ well density in $60-\mathrm{mm}$ culture dishes and subjected to culture at $37^{\circ} \mathrm{C}$. Incubation with vanillin oxime at 2 and $10 \mu \mathrm{M}$ concentrations was followed by removal of the medium and subsequently medium was replaced after every 3 days. Washing of cells in PBS, fixing for $10 \mathrm{~min}$ in methanol (anhydrous) was followed by staining with crystal violet solution $(0.1 \%)$. Staining was performed for $20 \mathrm{~min}$ at room temperature prior to calculation of colonies formed under light microscope (magnification, ×400; Carl Zeiss AG).

\section{Analysis of cell invasion}

Matrigel was adjusted to a concentration of $1 \mathrm{mg} / \mathrm{ml}$ using precooled medium devoid of the serum at $4^{\circ} \mathrm{C}$. Upper chambers having filters with $8 \mu \mathrm{m}$ pore-size were coated for $4 \mathrm{~h}$ at $37^{\circ} \mathrm{C}$ using Matrigel and set for solidification. The cells in groups of $4 \times 10^{5}$ were suspended in $350 \mu \mathrm{l}$ serum-free medium and then transwell chambers were put into the 24-well culture plate. Mixture of the cells was put into the upper chamber and the medium mixed with 20\% FBS was added into the lower chamber. Removal of the chamber and aspiration of the cell culture was followed by PBS washing of the cells and then fixing for $10 \mathrm{~min}$ in methanol (anhydrous). The cells were dyed for $10 \mathrm{~min}$ with crystal violet $(0.1 \%)$, washed in water, dried, and then mounted on the coverslips using neutral gum. Cell invasion was detected randomly in five fields using a light microscope (magnification $\times 200$; Carl Zeiss AG).

\section{Western blot analysis}

Caski cells treated with vanillin oxime were lysed using the RIPA lysis buffer mixed with PMSF protease inhibitor $(1 \mu \mathrm{M})$ on ice over $40 \mathrm{~min}$. Supernatant was isolated after lysate centrifugation at $4^{\circ} \mathrm{C}$ for $25 \mathrm{~min}$ at $13000 \times g$ and protein content was estimated using the BCA method. Protein samples $(30 \mu \mathrm{g}$ protein/lane) were separated on 10\% SDS-PAGE and transferred to PVDF membranes which were blocked by incubation with $5 \%$ skimmed milk powder for $2 \mathrm{~h}$. Membrane incubation with primary antibodies against p-ERK1/2 (ab196883; dilution 1:1,000), p-Akt (ab196883; dilution 1:1,000), Bcl2 (ab218123; dilution 1:1000) and HIF-1 $\alpha$ ((ab205833; dilution 1:1,000; all from Abcam) was performed for overnight at $4^{\circ} \mathrm{C}$. Washing with PBS-0.1\% Tween-20 (PBST) three times was followed by $1 \mathrm{~h}$ incubation at room temperature with horseradish peroxidase-conjugated secondary antibodies (1:5000; cat. no. ab6789; Abcam). Protein expression was analysed using Laser scanning imaging (LI-COR Biosciences) and ImageJ 6.0 system.

\section{Reverse transcription-quantitative PCR (RT-qPCR) analysis}

Total RNA was extracted from vanillin oxime treated Caski cells using TRIzol $^{\circledR}$ reagent (Invitrogen) and for determination of RNA purity and concentration the ultraviolet spectrophotometer (Tecan Group, Ltd.) was employed. The RNA samples were reverse transcribed to cDNA using the EcoDry ${ }^{\text {TM }}$ Premix (Takara Biotechnology Co., Ltd.). Conditions used for reverse transcription were $50 \mathrm{~min}$ at $42^{\circ} \mathrm{C}$, for inactivation of the reverse transcriptase $5 \mathrm{~min}$ at $98^{\circ} \mathrm{C}$ and reverse transcription product saving at $4^{\circ} \mathrm{C}$. The BeyoFast ${ }^{\mathrm{TM}}$ SYBR-Green quantitative PCR premix was used for detection of HIF-1 $\alpha$ expression. Conditions used for thermocycling were: denaturation for $8 \mathrm{~min}$ at $94^{\circ} \mathrm{C}, 38$ cycles for $12 \mathrm{sec}$ at $94^{\circ} \mathrm{C}$ and for $55 \mathrm{sec}$ at $58^{\circ} \mathrm{C}$. The PCR amplification was followed by plotting of the melting curve to determine HIF-1 $\alpha$ expression using the $2-{ }^{\Delta \Delta} \mathrm{Cq}$ method.

\section{Flow cytometry assay}

Caski cells at $2.5 \times 10^{5}$ cells $/ \mathrm{ml}$ distribution were collected as single-cell suspension and put into 96-well 
plates. After treatment with vanillin oxime cells were harvested, washed twice with PBS, and then dyed with Annexin V-FITC and PI for $20 \mathrm{~min}$ at $37^{\circ} \mathrm{C}$. The cells were subsequently analysed for apoptosis using the flow cytometry (BD FACSCalibur ${ }^{\mathrm{TM}}$; BD Biosciences). Apoptosis was analysed using the CellQuest Pro software (version 5.0; BD Biosciences).

\section{Statistical analysis}

Data expressed are the mean \pm S.D. of triplicate experiments carried out independently. Differences were determined statistically using one-way ANOVA, Bonferroni post hoc test and Unpaired $t$-test to compare two groups. Data were analysed using the SPSS 20 (IBM Corp.) software. Differences were taken as statistically significant at $P<0.05$.

\section{RESULTS AND DISCUSSION}

\section{Inhibition of Caski cell viability and promotion of ROS level by vanillin oxime}

Cervical cancer, a frequently diagnosed gynecological malignancy in females, was responsible for 311000 deaths in the year 2018 (Arbyn et al., 2020). Worldwide, cervical cancer has an incidence of around $13 \cdot 1$ cases in every 100000 women and it was diagnosed in $\sim 570000$ women in 2018 (Arbyn et al., 2020). Treatment strategy presently available for cervical cancer consists of surgical resection followed by radiotherapy in combination with chemotherapy (Menderes et al., 2016). Standard treatment that is effective for cervical cancer inhibition is yet to be established and is urgently required to be developed. Chemotherapeutics used against the cervical cancer are mainly confronted with challenges such as tumor recurrence and rapid distant organ metastasis (Geretto et al., 2017). Highly efficient and novel chemotherapeutic agents possessing least/ no side effects need to be developed for the treatment of the cervical cancer effectively
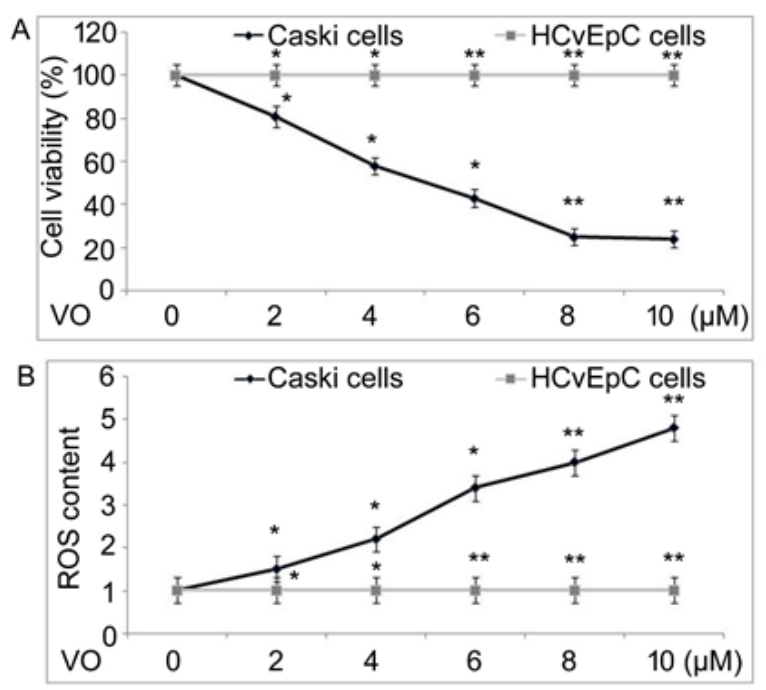

Figure 1. Effect of vanillin oxime on cell proliferation and ROS level.

(A) Caski and (HCvEpC) cells were incubated for $24 \mathrm{~h}$ with vanillin oxime and then analysed by MTT method for proliferation. (B) ROS level in Caski cells was detected after $24 \mathrm{~h}$ of incubation with 2 to $10 \mu \mathrm{M}$ concentrations of vanillin oxime. ${ }^{*} P<0.05$, ${ }^{*} P<0.01 \mathrm{vs}$. control cells.
(Geretto et al., 2017; Dueñas-González and Campbell, 2016).

In the present study viability changes by vanillin oxime in Caski and (HCvEpC) cells were measured following incubation with 2, 4, 6, 8 and $10 \mu \mathrm{M}$ concentrations by MTT method (Fig. 1A). Vanillin oxime treatment led to suppression of Caski cell proliferation, and the reduction was concentration dependent. Suppression in Caski cell proliferation by vanillin oxime treatment was maximum at $10 \mu \mathrm{M}$ concentration and remained constant at $10 \mu \mathrm{M}$. Vanillin oxime treatment also caused significant $(P<0.05)$ reduction in Caski cell proliferation at 2, 4 and $6 \mu \mathrm{M}$ concentrations. In ( $\mathrm{HCvEpC}$ ) cells vanillin oxime treatment could not affect proliferation at the tested (2 to $10 \mu \mathrm{M})$ concentrations. Vanillin oxime induced ROS level in Caski cells was detected at 2 to $10 \mu \mathrm{M}$ concentrations following incubation for $24 \mathrm{~h}$ (Fig. 1B). In vanillin oxime treated Caski cells ROS level showed an increase with enhancement in concentration from 2 to $10 \mu \mathrm{M}$.

\section{Vanillin oxime inhibits colony formation and cell invasion}

Colony formation inhibition by treatment with vanillin oxime in Caski cells was detected by treatment with concentrations of 2 and $10 \mu \mathrm{M}$ (Fig. 2A). Vanillin oxime treatment significantly $(P<0.0487)$ lowered the count of colonies in Caski cells compared to the control. In $10 \mu \mathrm{M}$ vanillin oxime treated cell cultures very few colonies were detected at $24 \mathrm{~h}$ compared to the control cultures. Treatment with vanillin oxime also lowered invasive abilities of Caski cells significantly $(P<0.05)$ at 2 and $10 \mu \mathrm{M}$ concentrations (Fig. 2B). Transwell assay showed that treatment with $10 \mu \mathrm{M}$ vanillin oxime lowered invasive abilities of Caski cells to greater extent compared to $2 \mu \mathrm{M}$ concentrations.

\section{Vanillin oxime induces Caski cell apoptosis}

A main anti-tumor mechanism for chemotherapeutics involving several targets to inhibit cell proliferation via complicated process is the apoptosis (Lunghi et al., 2008). Anti-tumor effect of some chemotherapeutics have been demonstrated to be associated with the damage induced by ROS formation (Sarkar et al., 2014; Qu et al., 2013). At baseline values ROS induces DNA synthe-

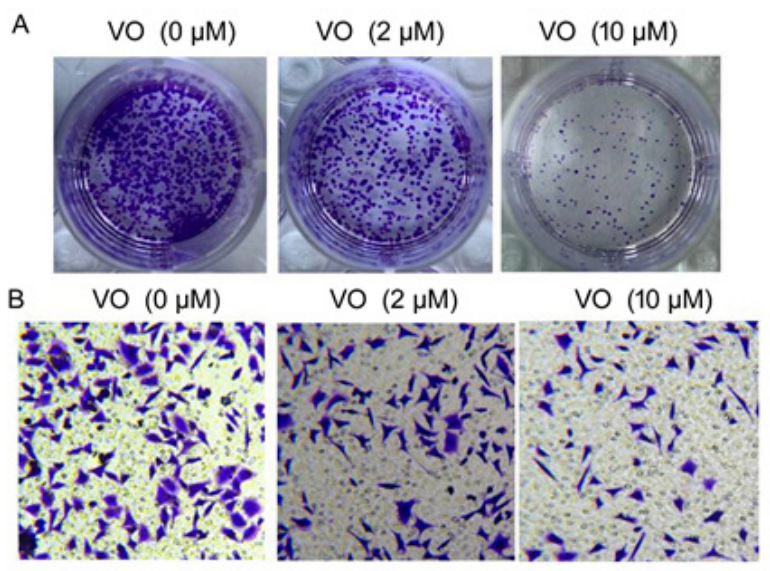

Figure 2. Effect of vanillin oxime on colony formation and invasive ability.

(A) Caski cells were incubated for $24 \mathrm{~h}$ with vanillin oxime and then analysed for colony-formation. (B) Invasive ability of Caski cells was monitored after $24 \mathrm{~h}$ of incubation with 2 and $10 \mu \mathrm{M}$ concentrations of vanillin oxime. 


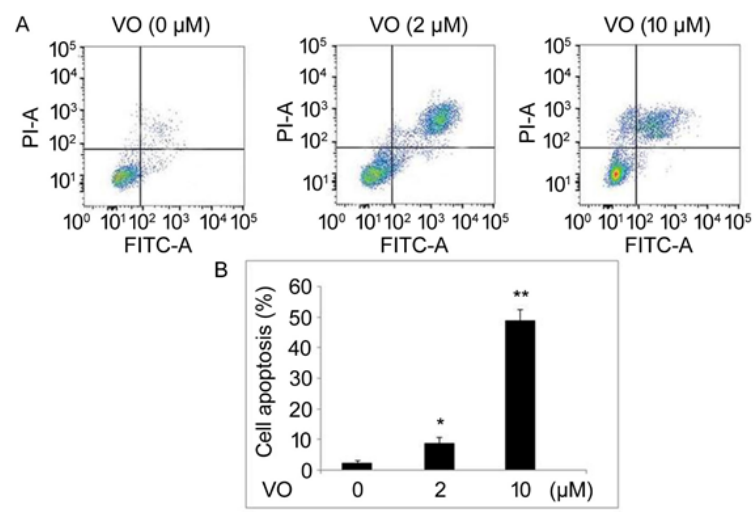

Figure 3. Effect of vanillin oxime on apoptosis activation. Caski cells were incubated for $24 \mathrm{~h}$ with vanillin oxime and then analysed for apoptosis activation. ${ }^{*} P<0.05$, ${ }^{*} P<0.01$ vs. control cells.

sis, subsequent cell mitosis and tumor cell proliferation (Hassani et al., 2013). Excessive formation of ROS leads to induction of apoptotic signals and causes necrotic cell death (Pollak et al., 2013). In the present study Caski cells after vanillin oxime treatment at 2 to $10 \mu \mathrm{M}$ concentrations were analysed for apoptosis by flow cytometry at $24 \mathrm{~h}$ (Fig. 3). Treatment with vanillin oxime significantly $(P<0.05)$ raised Caski cell apoptotic count in a dose-dependent way. Caski cell apoptotic count reached to $8.76 \%$ and $48.65 \%$, on incubation with 2 and $10 \mu \mathrm{M}$ concentrations of vanillin oxime, respectively.

\section{Vanillin oxime inhibits MMP expression}

Vanillin inhibits tumor migration and suppresses invasive abilities of liver cancer cells via targeting $\mathrm{NF}-x \mathrm{~B}$ expression and MMP activities (Liang et al., 2009). Angiogenesis as well as lamellipodia formation in lung cancer cells is inhibited through interfering with PI3K pathway by vanillin treatment (Lirdprapamongkol et al., 2010; Lirdprapamongkol et al., 2005; Lirdprapamongkol et al., 2009). Growth of cancer cells such as breast and cervical carcinoma is inhibited by vanillin through induction of apoptotic signals (Lirdprapamongkol et al., 2010; Lirdprapamongkol et al., 2005; Lirdprapamongkol et al., 2009). In the present study treatment of Caski cells with vanillin oxime at 2 to $10 \mu \mathrm{M}$ concentrations for $24 \mathrm{~h}$ was followed by MMP expression measurement by western blotting (Fig. 4). After treatment with vanillin oxime a prominent reduction in MMP-2 and -9 levels was observed in Caski cells compared to the control cells. The MMP-2 and -9 levels in Caski cells were reduced to minimum level by vanillin oxime treatment at $10 \mu \mathrm{M}$ concentration at $24 \mathrm{~h}$.

\section{Vanillin oxime inhibits malignancy protein levels}

In Caski cells vanillin oxime treatment at 2 to $10 \mu \mathrm{M}$ concentrations for $24 \mathrm{~h}$ was followed by protein expression determination by western blotting (Fig. 5). A prominent reduction in p-ERK1/2 and p-Akt levels was observed in Caski cells after treatment with vanillin oxime at 2 to $10 \mu \mathrm{M}$ concentrations. The Bcl-2 level in Caski cells also showed a remarkable reduction after vanillin oxime treatment in a dose-dependent way.

\section{Vanillin oxime inhibits HIF-1a expression}

Activation of HIF-1 $\alpha$ at a rapid rate plays crucial role in proliferation of tumor cells, their metastatic
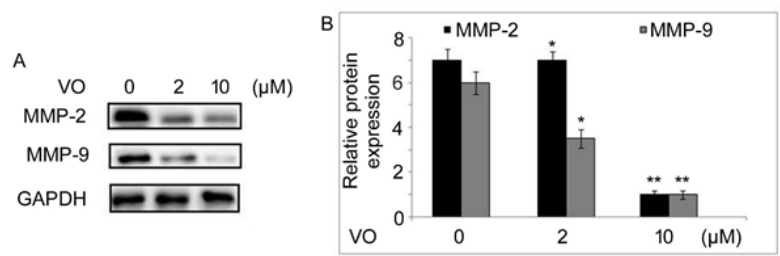

Figure 4. Effect of vanillin oxime on MMP expression.

Caski cells were incubated for $24 \mathrm{~h}$ with vanillin oxime and then MMP-2 and -9 levels were measured by western blotting. ${ }^{*} P<0.05$, ${ }^{* *} P<0.01$ vs. control cells.

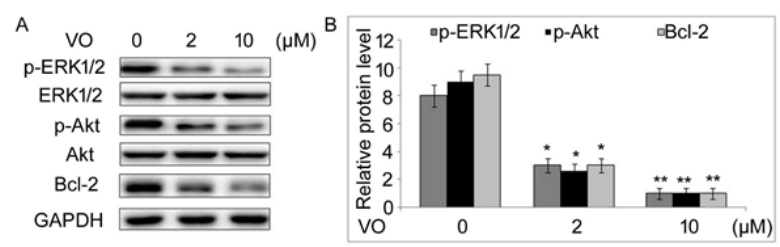

Figure 5. Effect of vanillin oxime on protein expression.

Caski cells were incubated for $24 \mathrm{~h}$ with vanillin oxime and then protein levels were measured by western blotting. ${ }^{*} P<0.05$, ${ }^{*} P<0.01$ vs. control cells.

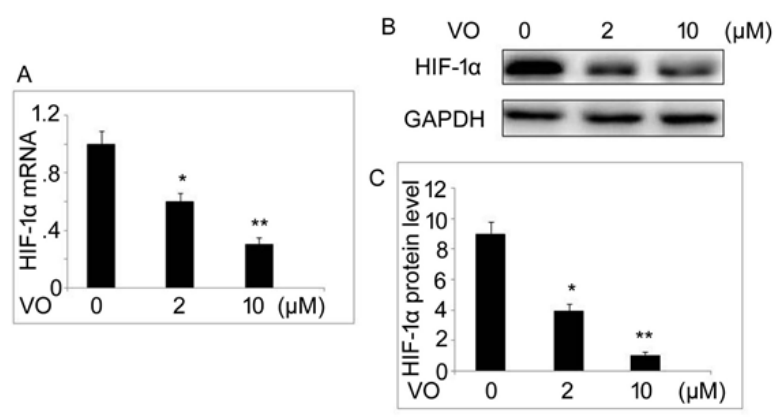

Figure 6. Effect of vanillin oxime on HIF-1a expression.

(A) Caski cells were incubated for $24 \mathrm{~h}$ with vanillin oxime and then analysed for HIF-1a mRNA expression by RT-PCR. (B) HIF-1a protein expression in Caski cells was measured by western blotting. ${ }^{*} P<0.05,{ }^{* *} P<0.01$ vs. control cells.

potential and infiltration abilities ( $\mathrm{Su}$ et al., 2011). It is also involved in development of resistance in tumor cells against chemotherapies and radiotherapy (Su et al., 2011). In the present study treatment with vanillin oxime caused a significant $(P<0.05)$ suppression in HIF- $1 \alpha$ mRNA expression at 2 to $10 \mu \mathrm{M}$ concentrations in Caski cells (Fig. 6A). After increasing the concentration of vanillin oxime from 2 to $10 \mu \mathrm{M}$, the reduction in HIF- $1 \alpha$ mRNA showed a dose-dependent reduction. HIF-1 $\alpha$ protein level also showed a prominent reduction in Caski cells after treatment with vanillin oxime at 2 to $10 \mu \mathrm{M}$ concentrations (Fig. 6B, C). Suppression in HIF-1 $\alpha$ protein level by vanillin oxime treatment at 24 $\mathrm{h}$ was maximum at $10 \mu \mathrm{M}$ concentration in Caski cells.

\section{CONCLUSION}

In summary, vanillin oxime inhibits cervical cancer proliferation, invasive abilities, induces apoptotic signalling, and elevates ROS production. Moreover, HIF-1 $\alpha$ expression inhibition, ERK1/2 and Akt protein downregulation is induced in cervical cancer cells after treatment with vanillin oxime. Therefore, vanillin oxime may 
be developed as an effective therapeutic agent for treatment of cervical cancer.

\section{Statement of Ethics}

The approval for present study was obtained from the Research Ethics Committee, Chifeng Second Hospital, Neimenggu Chifeng 024000, China. All the experimental procedures were conducted in accordance with the guidelines issued by National Institute of Health (NIH), China.

\section{Conflict of Interest}

The authors declare no conflict of interest.

\section{Author Contribution}

Guang-Min Zhang conceived and designed the study. Hong-jing Chen, Nai-ling Li and Qiang Gu performed all the experimental work, analysed and compiled the data. Hong-jing Chen and Nai-ling $\mathrm{Li}$ made literature survey and wrote the paper. All the authors approved the research article for publication.

\section{REFERENCES}

Arbyn M, Weiderpass E, Bruni L, de Sanjosé S, Saraiya M, Ferlay J, Bray F (2020) Estimates of incidence and mortality of cervical cancer in 2018: A worldwide analysis. Lancet Glob Health 8: e191e203. https://doi.org/10.1016/S2214-109X(19)30482-6

Chen Y, Liu C, Xie B, Chen S, Zhuang Y, Zhang S (2020) miR96 exerts an oncogenic role in the progression of cervical cancer by targeting CAV1. Mol Med Rep 22: 543550. https://doi.org/10.3892/ mmr.2020.11101

Diwanji N, Bergmann A (2018) An unexpected friendROS in apoptosisinduced compensatory proliferation: Implications for regeneration and cancer. Semin Cell Dev Biol 80: 7482. https://doi.org/10.1016/j. semcdb.2017.07.004

DueñasGonzález A, Campbell S (2016) Global strategies for the treatment of earlystage and advanced cervical cancer. Curr Opin Obstet Gynecol 28: 1117. https://doi.org/10.1097/GCO.0000000000000234

Global Burden of Disease Cancer Collaboration, Fitzmaurice C, Dicker D, Pain A, Hamavid H, Moradi-Lakeh M, MacIntyre MF, Allen C, Hansen G, Woodbrook R, Wolfe C, Hamadeh RR, Moore A, Werdecker A, Gessner BD, Te Ao B, McMahon B, Karimkhani C, Yu C, Cooke GS, Schwebel DC, Carpenter DO, Pereira DM, Nash D, Kazi DS, De Leo D, Plass D, Ukwaja KN, Thurston GD, Yun Jin K, Simard EP, Mills E, Park EK, Catalá-López F, deVeber G, Gotay C, Khan G, Hosgood HD 3rd, Santos IS, Leasher JL, Singh J, Leigh J, Jonas JB, Sanabria J, Beardsley J, Jacobsen KH, Takahashi K, Franklin RC, Ronfani L, Montico M, Naldi L, Tonelli M, Geleijnse J, Petzold M, Shrime MG, Younis M, Yonemoto N, Breitborde N, Yip P, Pourmalek F, Lotufo PA, Esteghamati A, Hankey GJ, Ali R, Lunevicius R, Malekzadeh R, Dellavalle R, Weintraub R, Lucas R, Hay R, Rojas-Rueda D, Westerman R, Sepanlou SG, Nolte S, Patten S, Weichenthal S, Abera SF, Fereshtehnejad SM, Shiue I, Driscoll T, Vasankari T, Alsharif U, Rahimi-Movaghar V, Vlassov VV, Marcenes WS, Mekonnen W, Melaku YA, Yano Y, Artaman A, Campos I, MacLachlan J, Mueller U, Kim D, Trillini M, Eshrati B, Williams HC, Shibuya K, Dandona R, Murthy K, Cowie B, Amare AT, Antonio CA, Castañeda-Orjuela C, van Gool CH, Violante F, Oh IH, Deribe K, Soreide K, Knibbs L, Kereselidze M, Green M, Cardenas R, Roy N, Tillmann T, Li Y, Krueger H, Monasta L, Dey S, Sheikhbahaei S, Hafezi-Nejad N, Kumar GA, Sreeramareddy CT, Dandona L, Wang H, Vollset SE, Mokdad A, Salomon JA, Lozano R, Vos T, Forouzanfar M, Lopez A, Murray C, Naghavi M. (2015) The global burden of cancer 2013. JAMA Oncol 4: 505527. https:// doi.org/10.1001/jamaoncol.2015.0735. Erratum in: JAMA Oncol 2015 Aug; 1(5):690. Jonas, Jost [corrected to Jonas, Jost B]; Tillman, Taavi [corrected to Tillmann, Taavi]

Geretto M, Pulliero A, Rosano C, Zhabayeva D, Bersimbaev R, Izzotti A (2017) Resistance to cancer chemotherapeutic drugs is determined by pivotal microRNA regulators. Am J Cancer Res 7: 13501371. PMID: 28670496; PMCID: PMC5489783

Hassani S, Ghaffari SH, Zaker F, Mirzaee R, Mardani H, Bashash D, Zekri A, Yousefi M, Zaghal A, Alimoghaddam K, Ghavamzadeh A (2013) Azidothymidine hinders arsenic trioxideinduced apoptosis in acute promyelocytic leukemia cells by induction of p21 and attenuation of G2/M arrest. Ann Hematol 92: 12071220. https://doi. org/10.1007/s00277-013-1763-8
Imanishi H, Sasaki YF, Matsumoto K, Watanabe M, Ohta T, Shirasu Y, Tutikawa K (1990) Suppression of 6-TG-resistant mutations in V79 cells and recessive spot formations in mice by vanillin. Mutat Res 243: 151-158. https://doi.org/10.1016/0165-7992(90)90038-L

Jambunathan N (2010) Determination and detection of reactive oxygen species (ROS), lipid peroxidation, and electrolyte leakage in plants. Methods Mol Biol 639: 292298. https://doi.org/10.1007/978-1-60761702-0 18

King AA, Shaughnessy DT, Mure K, Leszczynska J, Ward WO, Umbach DM, Xu Z, Ducharme D, Taylor JA, Demarini DM, et al., (2007) Antimutagenicity of cinnamaldehyde and vanillin in human cells: Global gene expression and possible role of DNA damage and repair. Mutat Res 616: 60-69. https://doi.org/10.1016/j.mrfmmm.2006.11.022

Lai HH, Li JN, Wang MY, Huang HY, Croce CM, Sun HL, Lyu YJ, Kang JW, Chiu CF, Hung MC, et al., (2018) HIF1 $\alpha$ promotes autophagic proteolysis of Dicer and enhances tumor metastasis. J Clin Invest 128: 625643. https://doi.org/10.1172/JCI89212

Liang JA, Wu SL, Lo HY, Hsiang CY, Ho TY (2009) Vanillin inhibits matrix metalloproteinase-9 expression through downregulation of nuclear factor-kappaB signaling pathway in human hepatocellular carcinoma cells. Mol Pharmacol 75: 151-157. https://doi. org/10.1124/mol.108.049502

Lirdprapamongkol K, Sakurai H, Suzuki S, Koizumi K, Prangsaengtong O, Viriyaroj A, Ruchirawat S, Svasti J, Saiki I (2010) Vanillin enhances TRAIL-induced apoptosis in cancer cells through inhibition of NF-kB activation. In Vivo 24: 501-506. PMID: 20668316

Lirdprapamongkol K, Sakurai H, Kawasaki N, Choo MK, Saitoh Y, Aozuka Y, Singhirunnusorn P, Ruchirawat S, Svasti J, Saiki I (2005) Vanillin suppresses in vitro invasion and in vivo metastasis of mouse breast cancer cells. Eur J Pharm Sci 25: 57-65. https://doi. org/10.1016/j.ejps.2005.01.015

Lirdprapamongkol K, Kramb JP, Suthiphongchai T, Surarit R, Srisomsap C, Dannhardt G, Svasti J (2009) Vanillin suppresses metastatic potential of human cancer cells through PI3K inhibition and decreases angiogenesis in vivo. I Agric Food Chem 57: 3055-3063. https://doi.org/10.1021/jf803366f

Lu L, Dong J, Wang L, Xia Q, Zhang D, Kim H, Yin T, Fan S, Shen $\mathrm{Q}$ (2018) Activation of STAT3 and $\mathrm{Bcl} 2$ and reduction of reactive oxygen species (ROS) promote radioresistance in breast cancer and overcome of radioresistance with niclosamide. Oncogene 37: 52925304. https://doi.org/10.1038/s41388-018-0340-y

Lunghi P, Giuliani N, Mazzera L, Lombardi G, Ricca M, Corradi A, Cantoni AM, Salvatore L, Riccioni R, Costanzo A, et al., (2008) Targeting MEK/MAPK signal transduction module potentiates ATOinduced apoptosis in multiple myeloma cells through multiple signaling pathways. Blood 112: 24502462. https://doi.org/10.1182/ blood-2007-10-114348

McClung NM, Gargano JW, Park IU, Whitney E, Abdullah N, Ehlers S, Bennett NM, Scahill M, Niccolai LM, Brackney M, Griffin MR, Pemmaraju M, Querec TD, Cleveland AA, Unger ER, Markowitz LE (2019) Estimated number of cases of highgrade cervical lesions diagnosed among womenUnited States, 2008 and 2016. MMWR Morb Mortal Wkly Rep 68: 337343. https://doi.org/10.15585/mmwr. mm6815a1

Menderes G, Black J, Schwab CL, Santin AD (2016) Immunotherapy and targeted therapy for cervical cancer: An update. Expert Rev Anticancer Ther 16: 8398. https://doi.org/10.1586/14737140.2016.11 21108

Pollak M (2013) Targeting oxidative phosphorylation: Why, when, and how. Cancer Cell 23: 263264. https://doi.org/10.1016/j. ccr.2013.02.015

Qin H-L, Leng J, Zhang C-P, Jantan I, Amjad MW, Sher M, Naeemul-Hassan M, Hussain MA, Bukhari SNA (2016) Synthesis of $\alpha, \beta$ unsaturated carbonyl-based compounds, oxime and oxime ether analogs as potential anticancer agents for overcoming cancer multidrug resistance by modulation of efflux pumps in tumor cells. $J$ Med Chem 59: 3549-3561

Qu H, Tong D, Zhang Y, Kang K, Zhang Y, Chen L, Ren L (2013) The synergistic antitumor activity of arsenic trioxide and vitamin K2 in HL60 cells involves increased ROS generation and regulation of the ROSdependent MAPK signaling pathway. Pharmazie 68: 839845. PMID: 24273890

Sarkar S, Mukherjee S, Chattopadhyay A, Bhattacharya S (2014) Low dose of arsenic trioxide triggers oxidative stress in zebrafish brain: Expression of antioxidant genes. Ecotoxicol Environ Saf 107: 18. https://doi.org/10.1016/j.ecoenv.2014.05.012

Sousa DMDN, Chagas ACMA, Vasconcelos CTM, Stein AT, Oriá MOB (2018) Development of a clinical protocol for detection of cervical cancer precursor lesions. Rev Lat Am Enfermagem 26: e2999. https://doi.org/10.1590/1518-8345.2340.2999

Su M, Gong XJ, Zhou X (2019) Research progress in mechanism of traditional Chinese medicine active ingredients against cervical cancer. Zhongguo Zhong Yao Za Zhi 44: 675684 (In Chinese). https://doi. org/10.19540/j.cnki.cjcmm.20181220.002 
Sun X, Jia H, Xu Q, Zhao C, Xu C (2019) Lycopene alleviates H2O2induced oxidative stress, inflammation and apoptosis in bovine mammary epithelial cells via the NFE2L2 signaling pathway. Food Funct 10: 62766285. https://doi.org/10.1039/C9FO01922G

Sun RC, Board PG, Blackburn AC (2011) Targeting metabolism with arsenic trioxide and dichloroacetate in breast cancer cells. Mol Cancer 10: 142. https://doi.org/10.1186/1476-4598-10-142

Su W, Huang L, Ao Q, Zhang Q, Tian X, Fang Y, Lu Y (2011) Noscapine sensitizes chemoresistant ovarian cancer cells to cisplatin through inhibition of HIF1 $\alpha$. Cancer Lett 350: 9499. https://doi. org/10.19080/OMCIJ.2019.09.555757

Srinivasan K, Platel K, Rao MVL (2008) Hypotriglyceridemic effect of dietary vanillin in experimental rats. Eur Food Res Technol 228: $103-$ 108. https://doi.org/10.1007/s00217-008-0911-1

Walton NJ, Mayer MJ, Narbad A (2003) Vanillin, Phytochemistry 63: 505-515. https://doi.org/10.1016/s0031-9422(03)00149-3

Wang G, Li Y, Yang Z, Xu W, Yang Y, Tan X (2018) ROS mediated $\mathrm{EGFR} / \mathrm{MEK} / \mathrm{ERK} / \mathrm{HIF} 1 \alpha$ loop regulates glucose metabolism in pancreatic cancer. Biochem Biophys Res Commun 500: 873878. https:// doi.org/10.1016/j.bbrc.2018.04.177

Wei KR, Chen WQ, Zhang SW, Zheng RS, Wang YN, Liang ZH (2012) Epidemiology of uterine corpus cancer in some cancer registering areas of China from 20032007. Zhonghua Fu Chan Ke $\mathrm{Za} \mathrm{Zhi}$ 6: 445451 (In Chinese). PMID: 22932112

Yang J, Li J, Sun M, Chen K (2014) Studies of traditional Chinese medicine monomer on HeLa cell of cervical cancer. Pak J Pharm Sci 27 (4 Suppl): S1063S1068. PMID: 25016267

Yang MH, Zang YS, Huang H, Chen K, Li B, Sun GY, Zhao XW (2014) Arsenic trioxide exerts antilung cancer activity by inhibiting angiogenesis. Curr Cancer Drug Targets 14: 557566. https://doi.org/10 $.2174 / 1568009614666140725090000$

Zhang Y, Yan J, Wang L, Dai H, Li N, Hu W, Cai H (2017) HIF1 $\alpha$ promotes breast cancer cell MCF7 proliferation and invasion through regulating miR210. Cancer Biother Radiopharm 32: 297301. https://doi.org/10.1089/cbr.2017.2270 